\title{
Implementation of Temperature Monitoring System in Seaweed Drying Room
}

\author{
Purnamawati $^{\mathrm{a},{ }^{*}}$, Muhammad Yahya ${ }^{\text {a }}$, Jamaluddin ${ }^{\mathrm{a}}$, Muhammad Akil ${ }^{\mathrm{a}}$ \\ ${ }^{a}$ Universitas Negeri Makassar, Makassar, 90224, Indonesia \\ Corresponding author: " purnamawati@unm.ac.id
}

\begin{abstract}
It is necessary to install a monitoring tool to improve the quality of seaweed dried in the drying room of Agricultural Technology Education, Engineering Faculty of Universitas Negeri Makassar. This drying room utilizes a solar dryer as the primary source of heat. This study aims to build and develop a monitoring system in the seaweed drying room. The methods used in this paper have been designed method consisting of two parts, such as hardware and software design. The hardware is an electronic board composed of sensors, Arduino Mega, driver relay, display, RTC, SD card, and power supply. All these kits are connected with various functions in a system that records temperature data in real-time. The software is an Arduino IDE with an integrated program to record temperature data every 15 minutes and show it on the GLCD. The monitoring circuit's testing results and the controlling system showed that it could function well indicated by the implementation without technical obstacles. The results showed that the highest temperature and the smallest humidity in the drying room were $63.77 \mathrm{oC}$ and $17.25 \%$, respectively, and occurred from 11:45 to 12:15. The average temperature and humidity of the air in the drying room during the study were $51.04 \mathrm{oC}$ and $34.7 \%$, respectively. Based on these values, this system can help the process of air circulation in the drying room and optimize the drying process of seaweed.
\end{abstract}

Keywords - Monitoring; temperature; humidity; seaweed dried.

Manuscript received 30 Nov. 2020; revised 12 Jan. 2021; accepted 28 Apr. 2021. Date of publication 31 Oct. 2021. IJASEIT is licensed under a Creative Commons Attribution-Share Alike 4.0 International License.

\section{INTRODUCTION}

Seaweed is one of the most abundant biological resources in Indonesian waters, with the most seaweed species compared to other countries [1]. Post-harvest handling is a series of seaweed agribusiness activities crucial in producing a good quality seaweed product. This activity must be done carefully from the harvest process and method, drying, packaging, and storing. To meet export and domestic industry requirements, seaweed must-have in better quality.

Post-harvest handling of seaweed requires serious attention to get superior quality. One way that can be used to optimize the quality of dried seaweed is to improve the drying process. At present, farmers are still using the traditional drying method, such as tarpaulin and bamboo tables. This method greatly influenced the quality of seaweed and has several disadvantages, such as requiring longer drying time and the seaweed can get dirty, even more, it can get contamination by dust and sand particles and other impurities Surata et al. [2] and also airborne contamination (particulates, microbes, etc.) [3]. So, this current drying process can degrade the quality of seaweed products [4].
There are several methods of seaweed drying that had been used in many studies. The previous studies have used solar energy as a source of seaweed drying [2], [5], [6]. The study of Pradana et al. [7] and Sappati et al. [8] shows the use of an air dehumidification system with silica gel adsorbent to decrease the efficient drying process. The process study of Pradana et al. [7] tried to examine the drying time and temperature of moisture content and the rate of drying. The best condition in the drying process of seaweed is used temperature $50^{\circ} \mathrm{C}$ at 4 hours. The other study used dehumidified air to retain seaweed quality [4]. The result that the dehumidified air also affected drying time positively. The two above research used a sun dryer treatment directly, different from the Suherman et al. [9], using a solar dryer tool to make faster and best-dried seaweed products. Using this method can dry the material up to $12,2 \%$ water content within 16 hours. A similar study of Phang et al. [10] got the final moisture content of seaweed weight less than $5 \%$ for subsequent measurement.

Further research by Naim et al. [11] used a different method. It used an oven in the seaweed drying process. The oven seaweed dryer functions well. Seaweed drying can be 
done with the help of solar, sunlight, and oven [9]. Several studies before did not use the temperature and humidity sensor to monitor the drying room condition. Besides, the environmental condition should also be monitored to ensure that the room temperature does not exceed the safe limits that can damage the seaweed quality.

The system that can be used to monitor and control the temperature of the greenhouse is using an Arduino Uno viewing into the Labview [12], microcomputers and programmable logic control (PLC) [13], Arduino Uno and Ethernet shield [14]. Some sensors used to read the environment condition are wireless sensor network [15], using an Infrared Thermometer Camera [16], and ZigBee technology for data monitoring sensor-based [17].

The drying room of Agricultural Technology Education of Universitas Negeri Makassar is using the solar dryer too. But the room drying without having a temperature and humidity monitoring system to keep the condition stable. Therefore, a series of monitors/controls need to be installed to monitor and control environmental conditions. This study aimed to develop a circuit monitoring in the seaweed drying room which was completed by adding a temperature and humidity sensor, some circuit modules, including Real-Time Clock (RTC) and Micro SD. This monitoring system can store data quickly and accurately into the SD Card using the SHT temperature and Humidity sensor.

\section{MATERIAL AND METHOD}

\section{A. Design of Drying Room Systems and Sensor SHT10}

The seaweed room dryer in this study has an area of $15 \times 10$ meters with ironstone construction and room cover using polycarbonate material. Nearly $80 \%$ of the room is covered by carbonate material with the addition of 4 fans and exhausts to dispose of seaweed evaporation air.

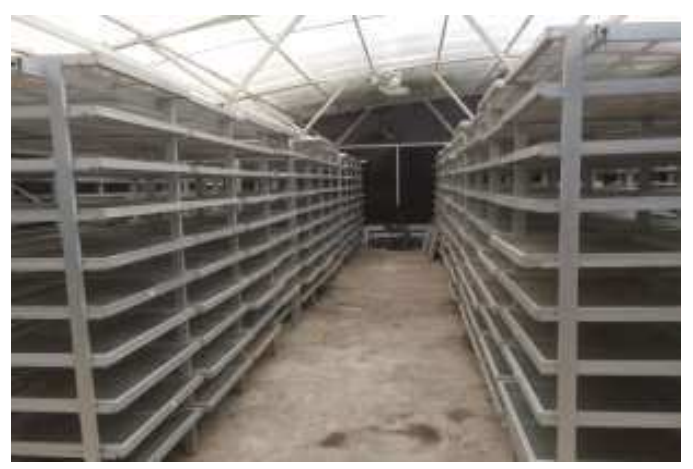

Fig. 1 Seaweed dryer tray

Inside the room, there are several rows of dryer trays made of aluminum. This drying chamber utilizes solar energy as the only source of drying. The design of a fully covered room by polycarbonate can maximize the heat generated by adequate air circulation. Temperature Start Input and Output initialization and humidity sensors use the SHT10 type placed proportionally on the dryer tray line to get the temperature and humidity data representing each dried seaweed storage tray (Fig. 1).

\section{B. Block Diagram and Flowchart}

This research design's block diagram consists of several main components, namely sensors, controllers, SD Card, RTC, Graphic Liquid Crystal Display (GLCD), driver relay, fan, and exhaust. Overall, the system can be described in block diagrams, as shown in Fig. 2.

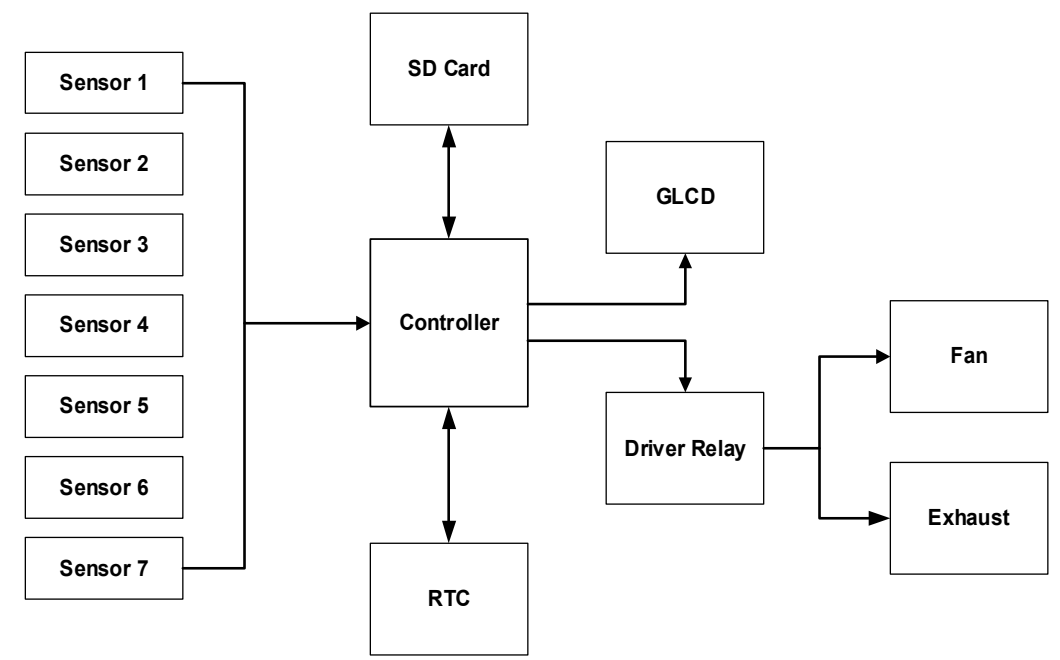

Fig. 2 Block diagram of temperature control system

Fig. 2 shows the automation system of temperature and humidity control of seaweed dryers in the drying room. It used 7 SHT 10 temperature sensors placed in the seaweed dryer tray. All temperature and humidity sensors are connected to the controller in Arduino Mega, which has many input-output ports. Hence, it allows the stem to increase the number of sensors and the control type of output. Each sensor sends a signal to Arduino in the form of temperature and humidity values. The signal is then processed by the processor based on the maximum temperature setting for seaweed. To make it easier to monitor the temperature sensor readings directly, a GLCD can be added which can display the temperature and humidity sensor values. RTC and SD cards are used as realtime timers and sensor data recording media, while to run fans and exhausts, a relay driver is needed, which functions as an active switch if it meets certain temperature conditions. 


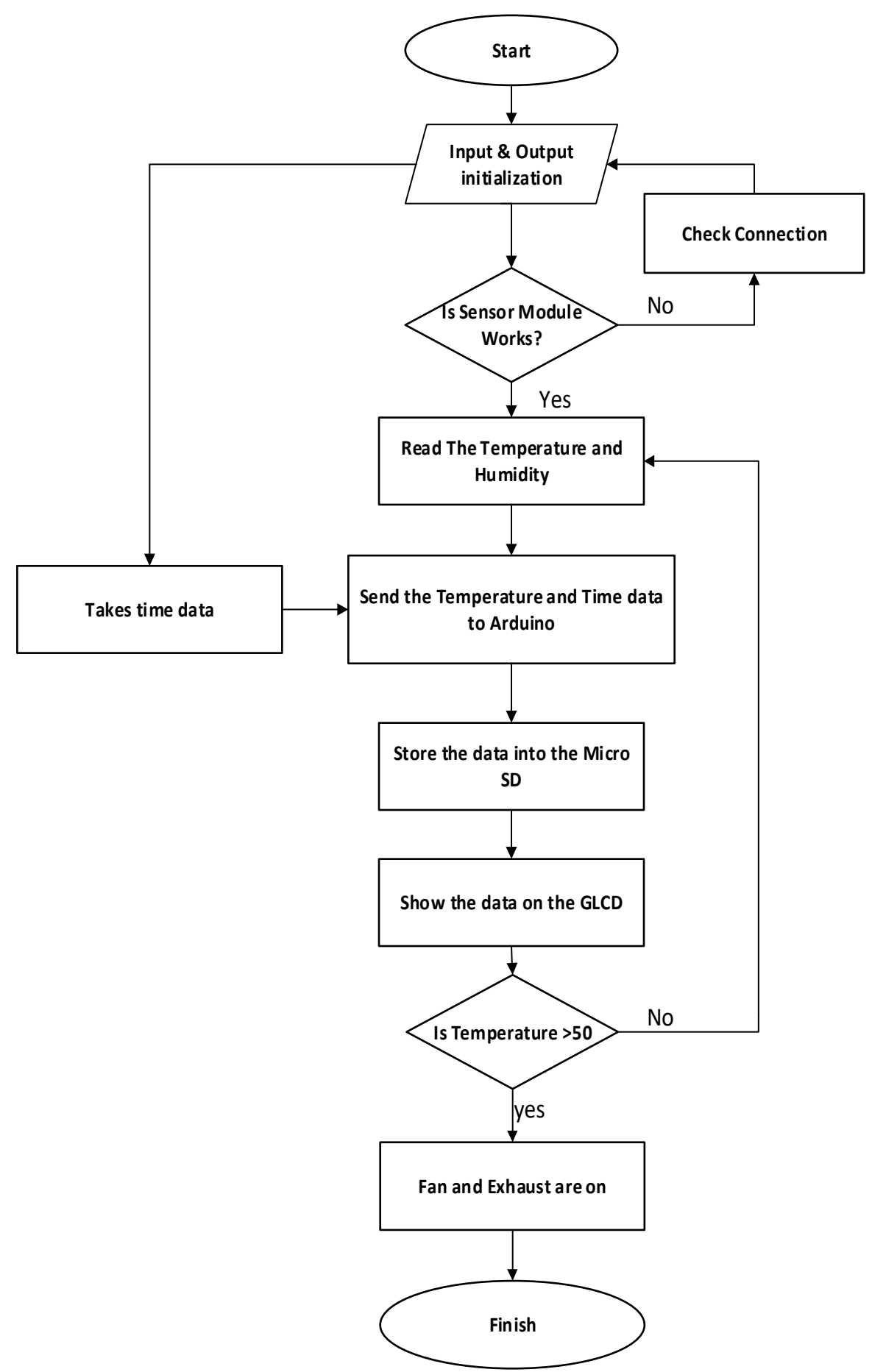

Fig. 3 Flowchart system

Fig. 3 shows the flowchart to test the system's initial stage with a series of temperature sensors and LCD graphs to display temperature and humidity values. Next, try the SD Card, RTC, and Driver Relay circuits. If the tests of each system function properly, then proceed with installing the whole system. Otherwise, the system will be repaired by looking for the cause of errors in the form of component damage or program errors. The entire system functioning properly was then connected to an integrated device and ready to be installed in a room dryer, followed by data retrieval that is analyzed according to the research problem.

\section{Hardware Design}

This system's hardware consists of several electronic circuits, including sensor circuits, graphic LCDs, RTC circuits, micro-SD adapters, regulator circuits, and relay modules. Each component was interlocked with their respective functions that are shown in Fig. 4. 


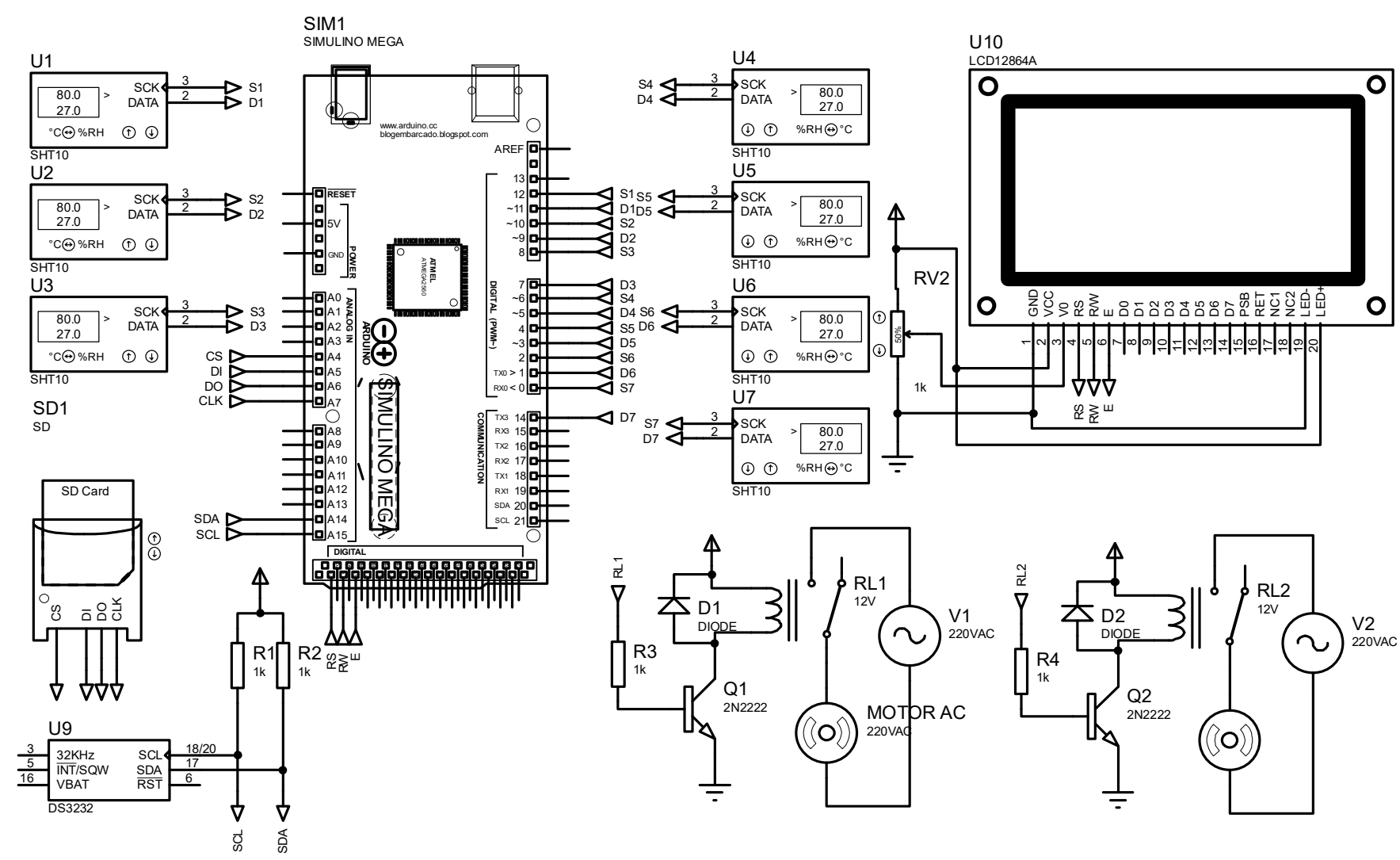

Fig. 4 The whole system circuit.

Fig. 4 is a complete series of temperature and humidity sensors. The SHT10 sensor type has a reading ability between $-40{ }^{\circ} \mathrm{C}$ to $123.8{ }^{\circ} \mathrm{C}$ with a reading accuracy level of $\pm 0.5{ }^{\circ} \mathrm{C}$. Meanwhile, the humidity that can be read is in the range of $0 \%$ to $100 \%$. This sensor consists of sensor elements and signal processing in packaging with an output in the form of a fully calibrated digital signal. The application of these sensors guarantees excellent reliability and long-term stability.

The LCD circuit is used as an information display in the form of temperature and humidity values. The LCD type is the Graphics LCD with a $128 \times 64$ bit pixel area. The LCD is different from the LCD Character. The advantage of graphic LCD is that it can display characters in the form of images that have been instructed into bitmap files with maximum pixel area according to the type of graphic LCD used.

RTC is used as a time reference for hours, minutes, and even seconds. Utilizing the RTC, temperature and humidity data can be obtained in real-time and recorded using an SD Card. The recording results are stored in the form of a text file. To run the fan and exhaust with a 220 Volt AC voltage source, additional circuit in the form of a relay driver is needed. This circuit can be controlled digitally, so Arduino can be used as a control source to activate the relay driver circuit. Arduino IDE is the software used in creating programs for all the system functions. The program is made by following the standard syntax for the Arduino IDE, although only a few basic instructions require adjustments because, in general, Arduino programming is almost the same as the $\mathrm{C}$ programming language.

\section{RESULTS AND DISCUSSION}

\section{A. Hardware Module}

The hardware module that consists of several electronic boards is integrated into the main circuit (Fig. 5). The description of each board in sequence according to the number is (1) a series of sockets that can be connected to the SHT10 sensors, (2) the Arduino Mega module, (3) the SD Card module, (4) the voltage stabilizer circuit module, (5) RTC module, (6) GLCD Circuit Socket, and (7) On-Off switch connected to $12 \mathrm{~V} 10 \mathrm{~A}$ Power Supply Switching.

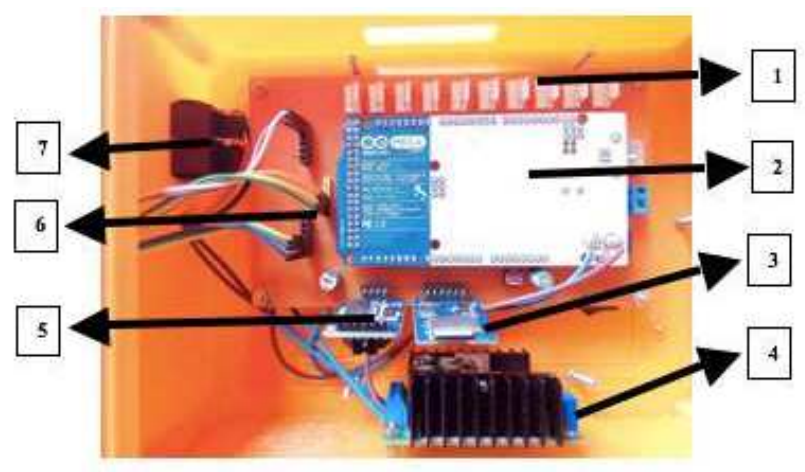

Fig. 5 Main series of monitoring systems and drying room controller

\section{B. SHT10 and GLCD sensors}

The SHT10 sensor continuously detects the temperature and humidity of the seaweed drying room. The resulting digital data is sent to the Arduino Mega controller circuit for processing and displaying on the GLCD (Fig. 6). To display 
temperature and humidity information data on the GLCD, it follows the Arduino program syntax.

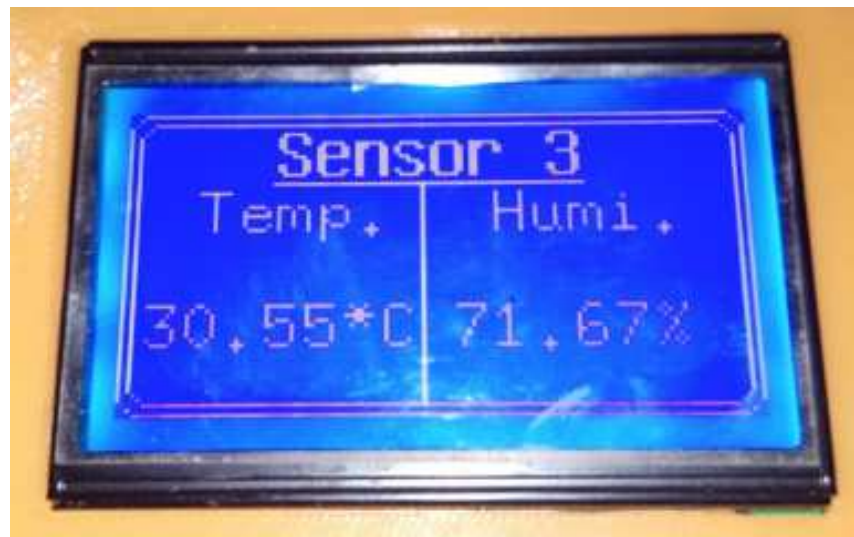

Fig. 6 Display of temperature and humidity data on the GLCD

Fig. 6 shows the temperature and humidity reading information on sensor module 3 . The temperature read value is $30.55{ }^{\circ} \mathrm{C}$ and is located under the Temp variable. While the humidity is $71.67 \%$ under the humidity variable. This display applies to all sensors installed in the seaweed dryer tray, but what distinguishes it is the title of the sensor name that appears at the top adjusted with what the sensor read. The GLCD circuit displays sensor data from sensor 1 to sensor 7 , automatically alternating with a time lag of 3 seconds. Following is a fragment of the program syntax to display information on GLCD, as shown in Fig. 7.

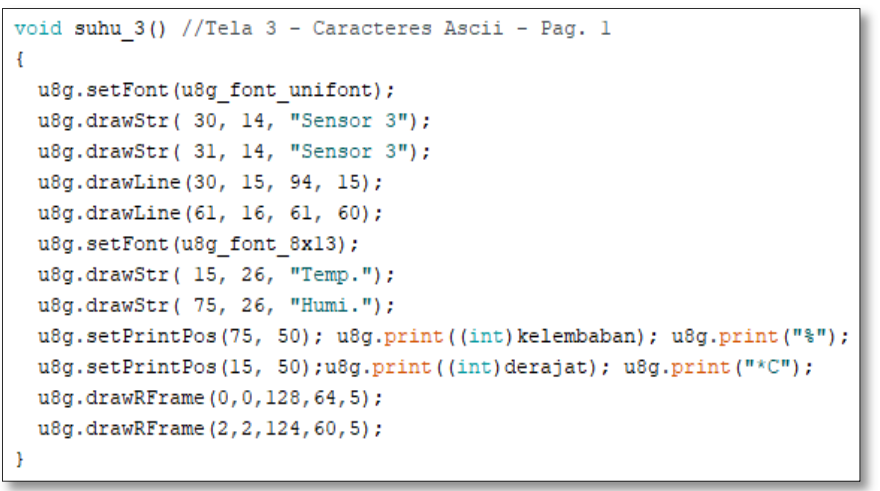

Fig. 7 Piece of one of the Sensor data display programs 3

The program shown in Fig. 7 shows that the u8g.drawStr command displays string data constantly according to the text or words inside the brackets (beginning and ending with quotation marks). The word will be displayed in the GLCD with the font position in the 30th column and row 14. While to display temperature data whose dynamic value can change at any time, a variable is used. These variables must be declared in advance in the main program fragment. In Fig. 7, the variable is shown to display temperature data using the temperature (T) 3 variable, while humidity uses the relative humidity $(\mathrm{RH}) 3$ variable. To display variable data using the u8g.setPrintPos instruction, then proceed with u8g.print (T3).

\section{The Data Logger of Temperature and Humidity}

The data logger functions to record every change in temperature and humidity on each sensor. Not only that, but the data was also recorded, including the timing. Two modules can be used to perform temperature and humidity data loggers. These modules are the RTC module and SD Card. The time recorded in real-time starts from seconds, minutes, hours to years generated by the RTC module. Even this module can store data even though the power supply circuit was turned off.

All data needed, including temperature, humidity, and time, was recorded and stored in micro-SD. The recording was done every time a change of 1 minute. Recordings were saved in Text file format. Fig. 8 shows the data recording of temperature, humidity, and time.

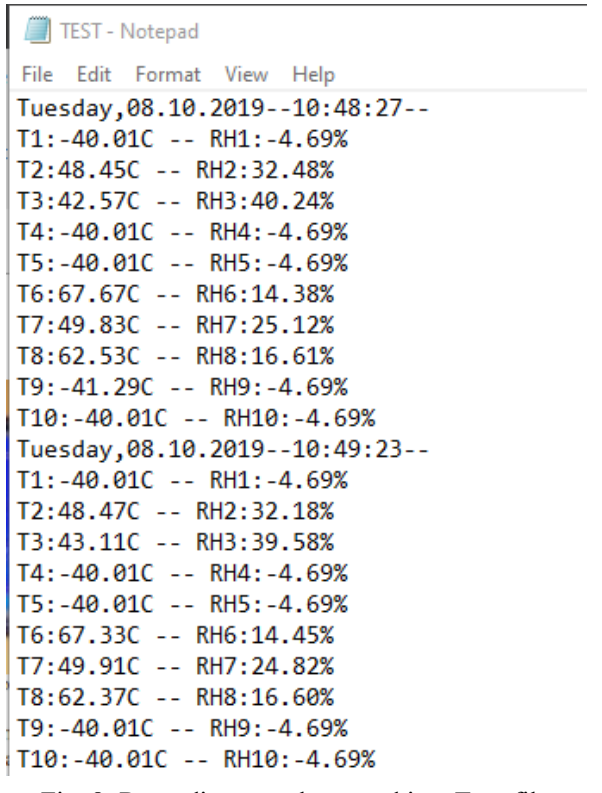

Fig. 8 Recordings results stored in a Text file

\section{Temperature and Humidity Monitoring Data}

The Drying room of seaweed consists of several tray dryers arranged in parallel, and each of them has 10 layers. Placement of the sensor is done evenly and can represent temperature and humidity readings in each tray used as a dryer. The SHT10 position sensor is placed in a tray that is used as a seaweed dryer. Therefore, there are 7 sensors installed that can represent the temperature and humidity readings proportionally. In addition to the temperature sensor, the controller circuit and the data viewer are also placed in the middle tray so that wires for data and communication lines from the sensor to the controller are not too long. The maximum cable size applied to the SHT10 sensor is 5 meters, with various considerations that the use of a long cable will easily produce noise and a large cable resistance and capacitance. This will affect the measurement results of the signal from the sensor [18].

Retrieval of temperature and humidity data carried out for 3 days at the same time with the drying of seaweed. Retrieval of temperature and humidity data is taken every change in 15 minutes. The sample time observed is starting at 10:00 until 17:00. Data stored on the SD Card is then entered into Excel to make it easier to do data analysis in diagram form. Temperature and humidity data processing is done based on the position of the sensor. 


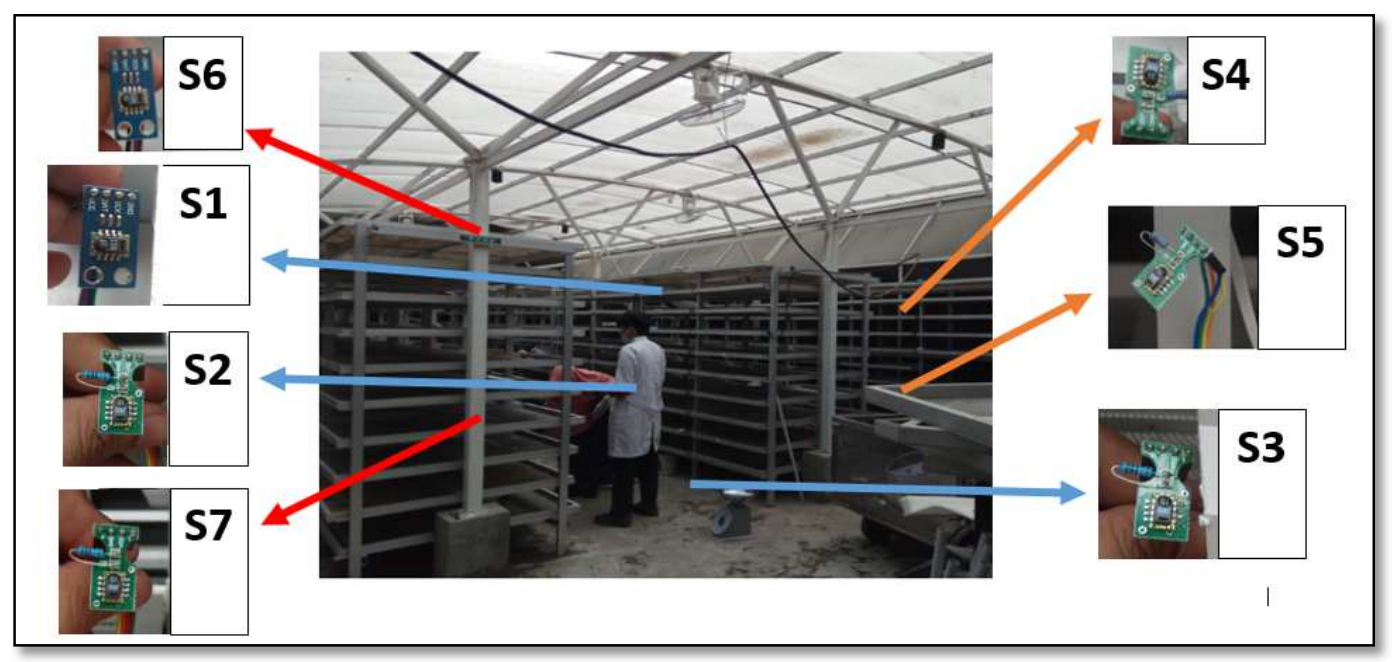

Fig. 9 Sensor SHT10 placement

There are three divisions of the sensor position as shown in Fig. 9:

- Sensors in the first tray layer (top layer) are sensor 1 (S1), sensor 4 (S4), and sensor 6 (S6),

- The sensors on the fifth tray (middle layer) are sensor 2 (S2), sensor 5 (S5), and sensor 7 (S7)

- The sensor on the ninth tray (the lowest layer) is sensor 3 (S3)

The Temperature and humidity observation data was obtained on the first day of drying with three divisions of sensor positions: the upper, middle, and bottom tray sections.

1) Position of the first tray (top): This type of sensor is a sensor that is placed on the top tray that sensor 1 (S1), sensor
4 (4), and sensor 6 (S6). Fig. 12 shows the temperature and humidity sensor readings on all three types of sensors. According to Fig. 10, the results of the temperature sensor data readings topmost layer tray highest temperature values obtained amounted to $63.77^{\circ} \mathrm{C}$, the minimum temperature reading value is $35.51{ }^{\circ} \mathrm{C}$, while the average value of the temperature on the top shelf is $51.04{ }^{0} \mathrm{C}$. The peak point of the temperature reading occurs from 11:45 to 12:15. Based on the graph, the sensor reading value $1(\mathrm{~S} 1)$ and sensor 6 (S6) has an average value that is almost the same as the difference of $0.2{ }^{0} \mathrm{C}$. While the average value of sensor reading $4(4)$ is $50.13{ }^{\circ} \mathrm{C}$.



Fig. 10 Temperature data at sensor 1 (S1), sensor 4 (S4), and sensor 6 (S6)

In Fig. 11, the highest humidity value was obtained at $57.71 \%$ (more than 50\%) at 17:00. This is due to the temperature of the air starting to fall. Humidity values tend to increase from 14.00 to 17.00 . Based on the graph, the lowest humidity value was obtained at $17.25 \%$ at $11: 45$. This value is contrary to the maximum readable temperature data at the same time. If the temperature and humidity data show values that tend to be opposite, then water vapor in seaweed is more quickly circulated in the drying chamber. Thus, humidity is inversely proportional to temperature if high temperatures affect humidity and vice versa. This condition is controlled by a series of monitoring so that the quality of seaweed quality level. 


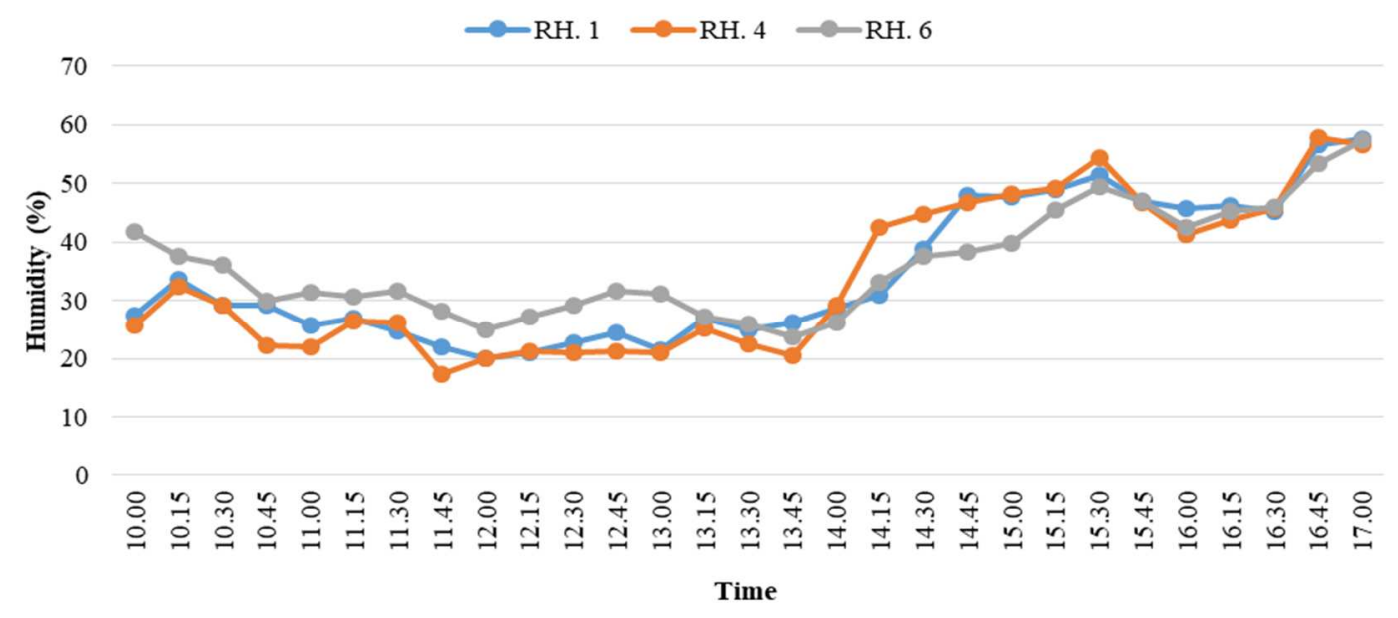

Fig. 11 Humidity data at sensor 1 (S1), sensor 4 (S4), and sensor 6 (S6)

2) Position of the fifth tray (middle): The type of sensors observed are sensors placed in the middle tray, namely sensor 2 (S2), sensor 5 (S5), and sensor 7 (S7) (Fig. 12). Based on the temperature sensor reading on tray 5 , the maximum temperature value is $52.13{ }^{\circ} \mathrm{C}$, the minimum temperature value is $34.04{ }^{0} \mathrm{C}$, and the average temperature reading is $42.49{ }^{\circ} \mathrm{C}$. The highest temperature read on tray 5 is lower than the maximum temperature reading results on tray 1 because the sensor position on tray 5 is in the middle, so that several stack trays block the heat distribution from the surface.

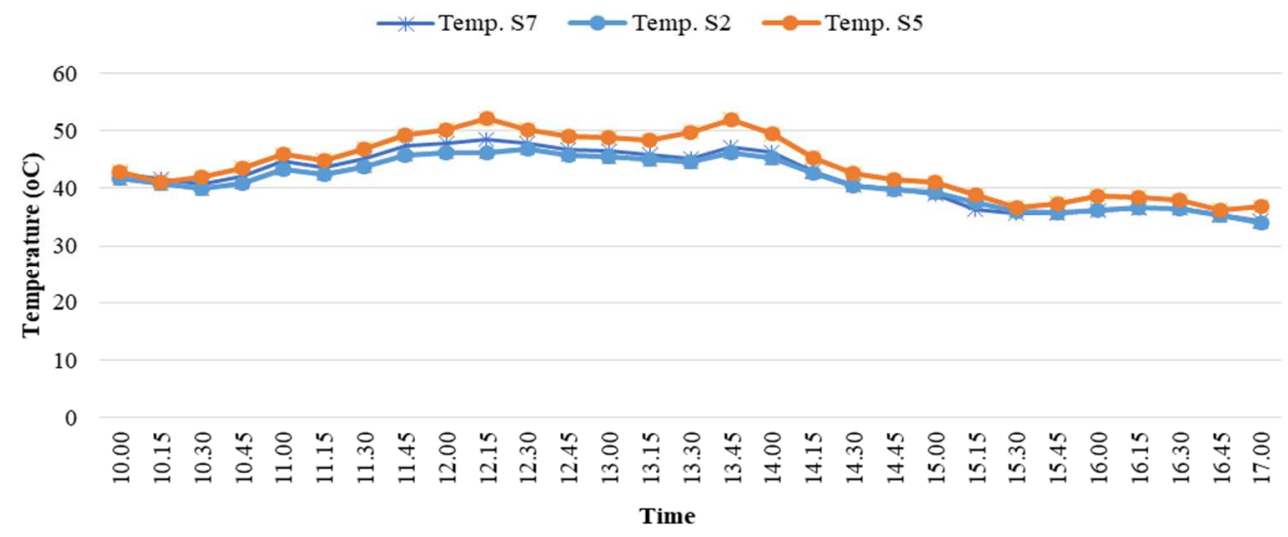

Fig. 12 Monitoring sensor readings on tray 5

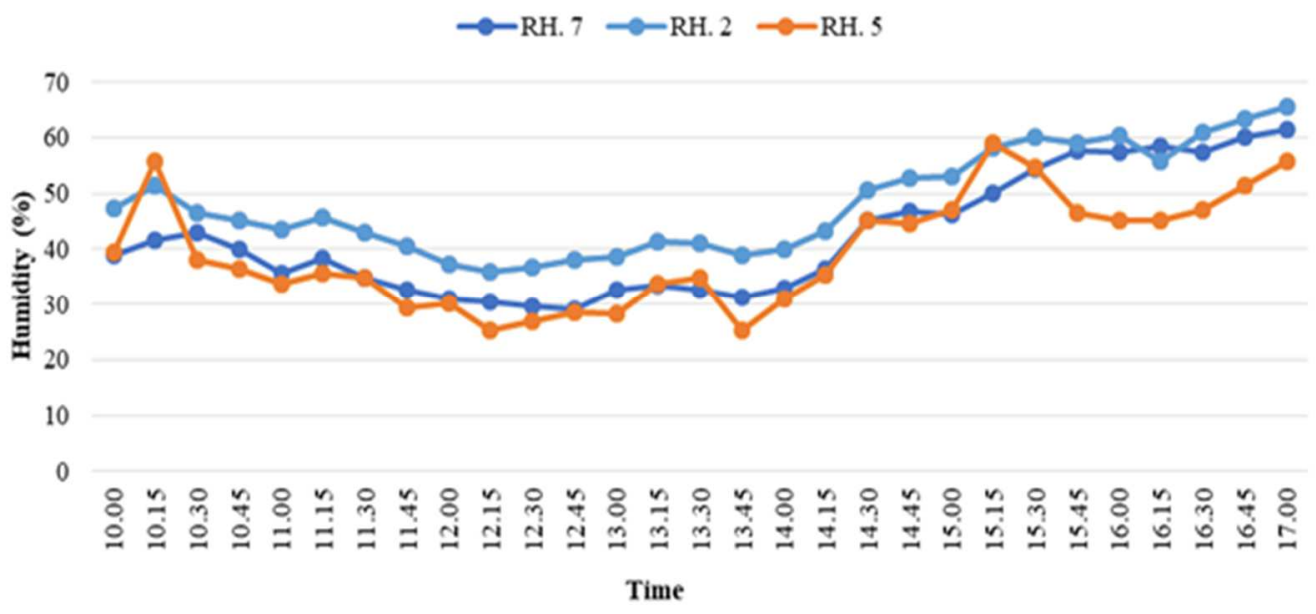

Fig. 13 Humidity monitoring on tray 5 


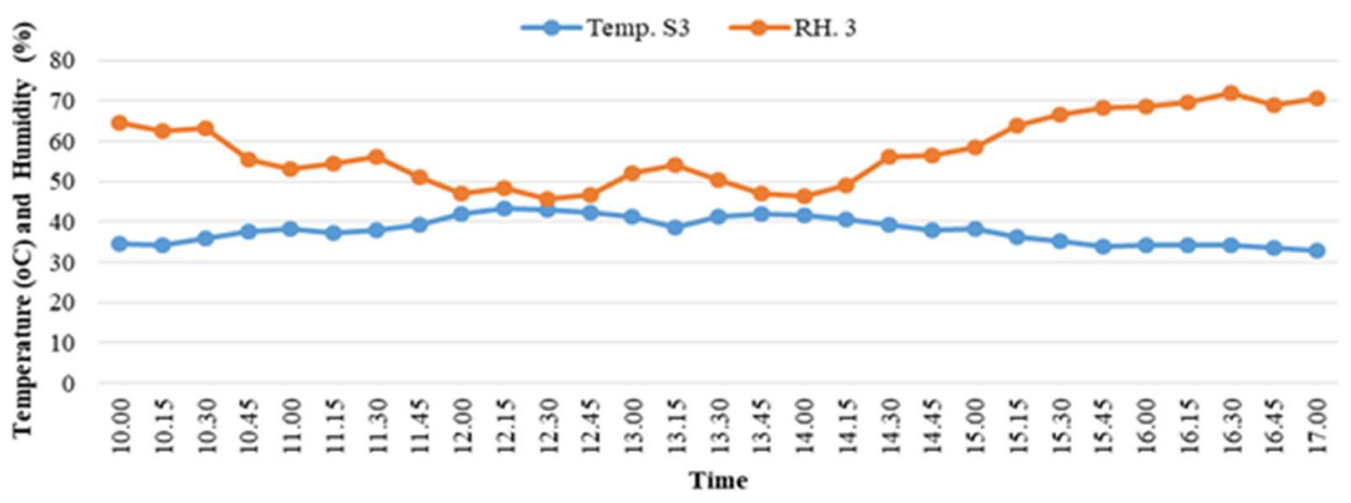

Fig. 14 Monitoring the temperature and humidity of the tray 9

Based on Fig. 13, the maximum humidity value read by sensor 2 is $65.61 \%$ at 17.00 , while the minimum humidity value is $25.14 \%$ at 13.45 at sensor 5 . The graph shows differences in humidity readings between sensor 2 , sensor 5 , and sensor 7 even though they are in the same position, tray 5 in the middle. The average value of humidity readings on sensor 2 is $48.01 \%$, while on sensor 5 is $39.41 \%$, so there is a difference in the two sensors' average reading that is equal to $8.6 \%$. Observation of temperature and humidity on sensor 3 on the lowest tray (tray 9) is shown in Fig. 14.

\section{E. Discussion}

Many studies have used sensors in designing room temperature control devices, household electrical appliances that produce remote home lighting control systems, and fire prevention systems due to gas leaks in the home [19]. Reading the condition of the drying chamber conducted by the SHT10 sensor produces data that the highest temperature value is $63.77^{\circ} \mathrm{C}$ and occurs from $11: 45$ to $12: 15$ at an average temperature of $51.04{ }^{\circ} \mathrm{C}$, while the humidity conditions at the same time are obtained the smallest value is $17.25 \%$. The value of the difference between temperature and humidity means that water vapor coming from seaweed can be circulated properly. Analysis of dry seaweed quality results of trials on dryers through the SHT10 sensor in real-time has a water content of $18.32 \%$, ash content of $45.61 \%$, fat content of $0.59 \%$, protein content of $9.20 \%$, and carbohydrate content of $26.28 \%$, whereas in conventional drying it has $18.52 \%$ water content, $48.90 \%$ ash content, $0.59 \%$ fat, $8.53 \%$ protein, and carbohydrate $23.46 \%$. Testing adds humidity to $80 \%$. This system can reach $80 \%$ with a tolerance level of $5 \%$ [20]. The higher the air temperature and airflow, the faster the drying time [4]. The study of Saptadi [21] states that the use of DHT11 and DHT2 2 with the result of a relative error above $10 \%$ indicates the need for recalibration. The difference in location (inside and outside the room) and the platform used (AVR or Arduino) does not affect the measurement results. All humidity measurement results show errors above $10 \%$ and temperature measurements ranging from $1-7 \%$. The research of [22] says that the use of the SHT10 sensor can control temperature and humidity accurately and in real-time. Goeritno et al [23] explained that the SHT11 sensor is very reliable because it has a measurement range from $0-100 \%$, RH with an absolute accuracy of $+/-3 \%$ when measuring humidity from $20 \%-80 \%$.

\section{CONCLUSIONS}

Implementation of a series of monitoring and controlling systems of seaweed drying room conditions can function properly without technical obstacles. Compose an SHT10 that uses sensors capable of properly handling ambient conditions. The measurement data is accurate, automatic, and worked digitally. The reading of the drying chamber conditions seaweed with a series of sensors SHT10 generates data in the form of the value of the highest temperature of $63.77^{\circ} \mathrm{C}$ and occurred at $11: 45$ until $12: 15$ with an average temperature of $51.04{ }^{\circ} \mathrm{C}$. Humidity conditions at the same time obtained the smallest at $17.25 \%$. According to the value of the difference between the temperature and the humidity, the water vapor was derived from seaweed can be circulated well.

\section{ACKNOWLEDGMENT}

This work was supported by Professorship Acceleration Grant Scheme (Skema Percepatan Penelitian Guru Besar), Universitas Negeri Makassar with the contract number: SP. DIPA-042.01:2.400964/2019. We are grateful to Prof. Husain Syam, the Rector of Universitas Negeri Makassar, for his assistance.

\section{REFERENCES}

[1] Suparmi and A. Sahri, "Mengenal Potensi Rumput Laut: Kajian Pemanfaatan Sumber Daya Rumput Laut Dari Aspek Industri Dan Kesehatan," Sultan Agung, vol. 44, no. 118, pp. 95-116, 2009.

[2] I. W. Surata, T. G. T. Nindhia, and I. K. A. Atmika, "Table Type Sun Drying for Seaweed Preservation," Appl. Mech. Mater., vol. 376, pp. 34-37, 2013,

https://doi.org/10.4028/www.scientific.net/AMM.376.34.

[3] U. O. Badmus, M. A. Taggart, and K. G. Boyd, "The effect of different drying methods on certain nutritionally important chemical constituents in edible brown seaweeds," J. Appl. Phycol., vol. 31, pp. 3883-3897, 2019, doi: https://doi.org/10.1007/s10811-019-01846-1.

[4] M. Djaeni and D. A. Sari, "Low Temperature Seaweed Drying Using Dehumidified Air," Procedia Environ. Sci., vol. 23, pp. 2-10, 2015, doi: 10.1016/j.proenv.2015.01.002.

[5] A. Fudholi, K. Sopian, M. Y. Othman, and M. H. Ruslan, "Energy and exergy analyses of solar drying system of red seaweed," Energy Build., vol. 68, no. A, pp. 121-129, 2014, doi: 10.1016/j.enbuild.2013.07.072.

[6] R. L. Patre, A. S. Mahajan, and A. R. Bhavsar, "Solar green house drying," Int. J. Eng. Dev. Res., vol. 6, no. 3, pp. 192-196, 2018.

[7] G. B. Pradana, K. B. Prabowo, R. P. Hastuti, M. Djaeni, and A. Prasetyaningrum, "Seaweed Drying Process Using Tray Dryer with Dehumidified Air System to Increase Efficiency of Energy and Quality Product," IOP Conf. Ser. Earth Environ. Sci., vol. 292, no. 1, 2019, doi: 10.1088/1755-1315/292/1/012070. 
[8] P. K. Sappati, B. Nayak, and P. VanWalsum, "Effect of Glass Transition on The Shrinkage of Sugar Kelp (Saccharina Latissima) During Hot Air Convective Drying," J. Food Eng., vol. 210, pp. 50 61, 2017, doi: https://doi.org/10.1016/j.jfoodeng.2017.04.018.

[9] S. Suherman, M. Djaeni, A. C. Kumoro, R. A. Prabowo, S. Rahayu, and S. Khasanah, "Comparison Drying Behavior of Seaweed in Solar, Sun and Oven Tray Dryers," MATEC Web Conf., vol. 156, pp. 1-4, 2018, doi: $10.1051 /$ matecconf $/ 201815605007$.

[10] H. Phang, C. Chu, S. Kumaresan, M. Rahman, and S. Yasir, "Preliminary Study of Seaweed Drying Under a Shade and in a Natural Draft Solar Dryer," Int. J. Sci. Eng., vol. 8, no. 1, pp. 10-14, 2015, doi: 10.12777/ijse.8.1.10-14.

[11] M. Naim, B. Burhanuddin, D. Lapondu, and R. Roslan, "Rancang Bangun Protipe Oven Pengering Rumput Laut untuk UKM di Wilayah Kabupaten Luwu Timur,” Din. J. Ilm. Tek. Mesin, vol. 10, no. 1, pp. 47-54, 2018, doi: 10.33772/djitm.v10i1.4845.

[12] I. Ardiansah, N. Bafdal, E. Suryadi, and A. Bono, "Greenhouse monitoring and automation using arduino: A review on precision farming and Internet of Things (IoT)," Int. J. Adv. Sci. Eng. Inf Technol., vol. 10, no. 2, pp. 703-709, 2020, doi: 10.18517/ijaseit.10.2.10249.

[13] L. Zheng, Y. Ying, and W. Wang, "Automatic Monitoring System of Temperature-Humidity for Lab," in 2010 Chinese Control and Decision Conference, 2010, pp. 4258-4261, doi: 10.1109/CCDC.2010.5498394.

[14] M. Simic, "Design and Development of Air Temperature and Relative Humidity Monitoring System with AVR Processor-Based Web Server," in 2014 International Conference and Exposition on Electrical and Power Engineering (EPE), 2014, pp. 038-041, doi: 10.1109/ICEPE.2014.6969864.

[15] Y. Y. Maulana, G. Wiranto, D. Kurniawan, I. Syamsu, and D. Mahmudin, "Online Monitoring of Shrimp Aquaculture in Bangka
Island using Wireless Sensor Network," Int. J. Adv. Sci. Eng. Inf. Technol., vol. 8, no. 2, pp. 358-364, 2018, doi: 10.18517/ijaseit.8.2.2428.

[16] S. Azhani et al., "Sensory and Physical Properties of Pla-duk-ra (Dried Fermented Catfish) at Different Conditions of Drying," Int. J. Adv. Sci. Eng. Inf. Technol., vol. 8, p. 1597, 2018, doi: https://www.researchgate.net/deref/http $\% 3 \mathrm{~A} \% 2 \mathrm{~F} \% 2 \mathrm{Fdx}$.doi.org\% $\% 2 \mathrm{~F}$ 10.18517\%2Fijaseit.8.4-2.7038.

[17] B. Chang and X. Zhang, "Design of indoor temperature and humidity monitoring system based on CC2430 and fuzzy-PID," 2011, doi: 10.1109/CSQRWC.2011.6037121

[18] A. B. Putranto, B. I. Laksono, and B. Nurdiyanto, "Aplikasi Sensor SHT11 Pada Pengukuran Suhu Tanah," J. Meteorol. dan Geofis., vol. 10, no. $1, \quad$ pp. 66-72, 2009, doi http://dx.doi.org/10.31172/jmg.v10i1.34.

[19] Purnomo and Purnamawati, "Pengendali Home Appliances Menggunakan Telepon Selluler Berbasis Mikrokontroller ATMEGA 16," JETC, vol. 12, no. 1, pp. 25-37, 2017.

[20] A. R. Agusta, J. Andjarwirawan, and R. Lim, "Implementasi Internet of Things Untuk Menjaga Kelembaban Udara Pada Budidaya Jamur," J. Infra, vol. 7, no. 2, pp. 95-100, 2019.

[21] A. H. Saptadi, "Perbandingan Akurasi Pengukuran Suhu dan Kelembaban Antara Sensor DHT11 dan DHT22 Studi Komparatif pada Platform ATMEL AVR dan Arduino," J. Inform. dan Elektron. 2015, doi: 10.20895/infotel.v6i2.73.

[22] X. Wang, "Temperature and Humidity Monitoring System Based on GSM Module," Int. J. Comput. Consum. Control, vol. 3, no. 1, pp. 4149, 2014.

[23] A. Goeritno, D. J. Nugroho, and R. Yatim, "Implementasi Sensor SHT11 untuk Pengkondisian Suhu dan Kelembaban Relatif Berbantuan Mikrokontroller," in Seminar Nasional Sains dan Teknologi, 2014, pp. 1-13. 